\title{
Hubungan Tingkat Pengetahuan Dokter dengan Kualitas Visum et Repertum Perlukaan di Rumah Sakit Wilayah Sumatera Barat Periode Januari 2011 sampai Desember 2012
}

\author{
M. Ridho Azhari ${ }^{1}$, Rika Susanti ${ }^{2}$, Noza Hilbertina ${ }^{3}$
}

\begin{abstract}
Abstrak
Visum et Repertum (VeR) perlukaan ialah salah satu bentuk VeR untuk korban hidup yang berguna sebagai alat bukti pengganti tubuh korban yang dibuat oleh seorang dokter sesuai permintaan tertulis dari penyidik. Terdapat beberapa faktor yang mempengaruhi kualitas VeR perlukaan salah satu nya tingkat pengetahuan dokter. Tujuan penelitian ini adalah menyelidiki hubungan antara tingkat pengetahuan dokter dengan kualitas VeR perlukaan. Metode penelitian menggunakan desain cross sectional study di delapan rumah sakit di wilayah Sumatera Barat yang memenuhi kriteri inklusi. Instrumen penelitian yang digunakan adalah kuesioner yang dikembangkan sendiri dan teknik skoring kualitas VeR dari FKUI. Hasil penelitian ini ditemukan bahwa rerata tingkat pengetahuan dokter sebesar $57.05 \%$ (cukup) dan rerata kualitas VeR perlukaan sebesar $19.67 \%$ (buruk). Hasil analisis bivariat dengan menggunakan uji korelasi produk moment diperoleh hasil tidak ditemukan adanya hubungan antara tingkat pengetahuan dokter dengan kualitas VeR perlukaan $p=0.485(p>0,05)$. Tidak terdapatnya hubungan dikarenakan setiap rumah sakit memiliki suatu format untuk membuat VeR perlukaan. Penelitian yang akan datang dapat menganalisis faktor lain yang mempengaruhi kualitas VeR dan instansi terkait diharapkan dapat memperbaiki pengarsipan, meningkatkan pengetahuan dokter terkait VeR dan menyediakan buku pedoman penulisan VeR.
\end{abstract}

Kata kunci: tingkat pengetahuan, kualitas VeR, VeR perlukaan

\section{Abstract}

Visum et Repertum (VeR) of injury is a form of VeR for living victim used as the evidence to represent the victim's body which is made by a doctor according to the written request from investigating officer. There are several factors influencing the quality of Ver of injury, one of which is the doctor's knowledge level. The objective of this study was to investigate the relation between doctor's knowledge level and the quality of VeR of injury by using Cross Sectional Study method. This study was conducted at eight hospitals in West Sumatera region that met the inclusion criteria. The research instruments used were the questionnaire developed by the reseacher and the quality scoring technique from Faculty of Medicine University of Indonesia. The results of this research showed that the average of doctor's knowledge level was $57.05 \%$ (fair) and the average of VeR of injury quality was $19.67 \%$ (bad). The result of bivariat analysis by using product moment correlation test showed that there is no any relation between doctor's knowledge level and the quality of VeR of injury $p=0.485$ ( $p>0,05)$. The relation was absent because every hospital has its own form in making the $V e R$ of injury. It is recommended for the future study to analyse other factors influencing the quality of $\mathrm{VeR}$ of injury dan hopefully this study can be useful for improve archiving, increase doctor's knowledge level and provide $V e R$ manuals book.

Keywords: knowledge level, quality of $\mathrm{VeR}$, VeR of injury

Affiliasi penulis: 1. Pendidikan dokter FK UNAND (Fakultas Kedokteran Universitas Andalas Padang), 2. Bagian IImu Kedokteran Forensik dan Medikolegal FK UNAND, 3. Bagian Patalogi Anatomi FK UNAND.
Korespondensi: M. Ridho Azhari, E-mail: ridhoazhari93@gmail.com, Telp: 08566117911 


\section{PENDAHULUAN}

Dalam upaya menegakkan hukum dan keadilan untuk menyelesaikan sesuatu perkara pengadilan, aparat hukum membutuhkan bukti yang berhubungan dengan perkara tersebut. Salah satu bukti yang sah seperti yang dikenal saat ini berupa Visum et Repertum (VeR) sebagai barang bukti pengganti tubuh korban. Visum et Repertum dibuat oleh dokter sesuai dengan permintaan tertulis dari pihak polisi penyidik. Hal ini sesuai dengan KUHAP pasal 133 ayat 1 tentang dasar pengadaan Visum et Repertum pada masa penyidikan. ${ }^{1-3}$

Menurut pengertiannya, Visum et Repertum ialah keterangan ahli tertulis yang dibuat dokter untuk kepentingan peradilan. Visum et Repertum merupakan alat bukti dalam proses peradilan yang tidak hanya memenuhi standar penulisan rekam medis, tetapi juga harus memenuhi hal yang diisyaratkan dalam sistem peradilan. $^{1-3}$

Pada saat ini permintaan pembuatan Visum et Repertum khususnya Visum et Repertum perlukaan semakin banyak karena sekitar $50-70 \%$ kasus yang datang ke rumah sakit terutama instalasi gawat darurat adalah kasus perlukaan atau trauma. Banyaknya permintaan pembuatan Visum et Repertum ini diiringi dengan banyak dijumpai kesalahan dalam pembuatan Visum et Repertum yang berakibat rendahnya kualitas Visum et Repertum itu sendiri. ${ }^{4}$

Penelitian yang telah dilakukan untuk mengetahui kualitas Visum et Repertum di rumah sakit di wilayah DKI Jakarta menunjukan Visum et Repertum hanya sebesar $15,4 \%$ yang berkualitas baik. ${ }^{5}$ Penelitian lain menunjukkan kualitas Visum et Repertum yang diteliti di Rumah Sakit Arifin Achmad Pekanbaru periode Januari 2004 - September 2007 $97,06 \%$ berkualitas buruk. ${ }^{6}$ Di wilayah Sumatera Barat penelitian telah dilakukan di enam Rumah Sakit di wilayah Sumatera Barat periode 1 Januari 2008 - 31 Desember 2008 dan didapatkan hasil pada RSUP M. Djamil berkualitas baik (78,78\%), RSUD Sungai Sapieh berkualitas sedang (50,17\%), RSAM Bukittinggi berkualitas sedang (74,39\%), RSUD Pariaman berkualitas buruk (22,92\%), RSUD Padang
Panjang berkualitas buruk (31,29\%), dan RSUD Solok berkualitas buruk (39,75\%). Ini menunjukkan kualitas Visum et Repertum masih sangat jauh dari yang diharapkan. ${ }^{7}$

Rendahnya kualitas Visum et Repertum ini juga dipengaruhi beberapa faktor yaitu status kepemilikan rumah sakit, status rumah sakit pendidikan, akreditasi rumah sakit, jumlah dokter ahli, jumlah dokter menetap, dan formasi visum yang dibuat sendiri. Faktor pengetahuan dokter pembuat Visum et Repertum juga merupakan salah satu faktor yang mempengaruhi kualitas Visum et Repertum. Untuk itu perlu diketahui tingkat pengetahuan dokter mengenai Visum et Repertum karena dokter pembuat visum termasuk dalam salah satu penyebab rendahnya kualitas Visum et Repertum. . $^{2,3,5}$

\section{METODE}

Penelitian ini dilaksanakan di rumah sakit Wilayah Sumatera Barat pada bulan November 2012 April 2013. Sampel penelitian ini adalah seluruh subjek yang dapat diperoleh.

Penelitian ini merupakan penelitian analitik observasional dalam bentuk rancangan cross sectional study, dimana variabel independen (tingkat pengetahuan dokter) dan variabel dependen (kualitas Visum et Repertum perlukaan), Pengolahan data dilakukan dengan uji korelasi produk moment menggunakan sistem komputerisasi.

\section{HASIL}

Penelitian dilakukan terhadap 15 subjek penelitian yang merupakan dokter pembuat VeR perlukaan. Sembilan rumah sakit yang dijadikan sampel, satu diantaranya menolak untuk dilibatkan dalam penelitan. Didapatkan hasil penelitian sebagai berikut:

\section{Tingkat Pengetahuan Dokter}

Distribusi frekuensi subjek penelitian berdasarkan tingkat pengetahuan dokter pembuat VeR Perlukaan di rumah sakit wilayah Sumatera Barat Periode 1 Januari 2011 - 31 Desember 2012 dapat dilihat pada tabel di bawah ini. 
Tabel 1. Frekuensi subjek penelitian berdasarkan tingkat pengetahuan di delapan rumah sakit

\begin{tabular}{lcc}
\hline Nama Rumah Sakit & Frekuensi & $\begin{array}{c}\% \text { Skor Rerata } \\
\text { (Kategori) }\end{array}$ \\
\hline RSAM Bukittinggi & 1 & $61.54 \%$ (Cukup) \\
RSUD Lubuk Basung & 3 & $64.10 \%$ (Cukup) \\
RSUD Pariaman & 2 & $46.15 \%$ (Kurang) \\
RSUD Payakumbuh & 2 & $50.00 \%$ (Kurang) \\
RSUD Padang Panjang & 2 & $76.92 \%$ (Baik) \\
RSUD Sawahlunto & 2 & $50.00 \%$ (Kurang) \\
RSUD Solok & 1 & $61.54 \%$ (Cukup) \\
RSUD Batusangkar & 2 & $46.15 \%$ (Kurang) \\
\hline \multicolumn{2}{c}{ Rerata } & \\
\hline
\end{tabular}

Pada Tabel 1 didapatkan tingkat pengetahuan pengetahuan terendah adalah $46,15 \%$ dan tertinggi $76,92 \%$. Rata-rata tingkat pengetahuan dokter pada penelitian adalah 57,05\% (Cukup).

\section{Kualitas Visum et Repertum Perlukaan}

Distribusi frekuensi Visum et Repertum Perlukaan di rumah sakit Wilayah Sumatera Barat periode 1 Januari 2011 - 31 Desember 2012 yang berjumlah 838 data dapat dilihat pada tabel ini.

Tabel 2. Frekuensi Visum et Repertum perlukaan di rumah sakit wilayah Sumatera Barat berdasarkan kualitas

\begin{tabular}{lll}
\hline Nama Rumah Sakit & Frekuensi & $\begin{array}{l}\text { \%Rata-rata } \\
\text { (Kategori) }\end{array}$ \\
\hline RSAM Bukittinggi & 42 & $38.60 \%$ (Buruk) \\
RSUD Lubuk Basung & 161 & $29.83 \%$ (Buruk) \\
RSUD Pariaman & 143 & $29.08 \%$ (Buruk) \\
RSUD Payakumbuh & 190 & $50.25 \%$ (Sedang) \\
RSUD Padang Panjang & 32 & $45.15 \%$ (Buruk) \\
RSUD Sawahlunto & 77 & $64.85 \%$ (Sedang) \\
RSUD Solok & 62 & $59.78 \%$ (Sedang) \\
RSUD Batusangkar & 131 & $29.80 \%$ (Buruk) \\
\hline Rata-rata & & $19.67 \%$ (Buruk) \\
\hline
\end{tabular}

Kualitas Visum et Repertum terendah adalah $29,08 \%$ dan tertinggi 64,85\% dengan rerata kualitas adalah 19,67\% (Buruk).
3. Hubungan antara Tingkat Pengetahuan Dokter dengan Kualitas Visum et Repertum Perlukaan

Pada Tabel 3 didapatkan nilai $\mathrm{p}=0,485$ $(>0,05)$. Hasil uji statistik tersebut dapat disimpulkan bahwa tidak terdapat hubungan signifikan antara tingkat pengetahuan dokter dengan kualitas Visum et Repertum Perlukaan.

Tabel 3. Hubungan antara tingkat pengetahuan dokter dengan kualitas Visum et Repertum perlukaan di delapan rumah sakit.

\begin{tabular}{ccccc}
\hline Tingkat & \multicolumn{2}{c}{ Kualitas Visum et } & & \\
Pengetahuan & Repertum Perlukaan & r & P \\
Dokter & Buruk & Sedang & & \\
\hline Kurang & $2(50,0 \%)$ & $2(50,0 \%)$ & & \\
Cukup & $2(66,7 \%)$ & $1(33,3 \%)$ & $-0,291$ & 0,485 \\
Baik & $1(100,0 \%)$ & $0(0 \%)$ & & \\
\hline
\end{tabular}

\section{PEMBAHASAN}

\section{Tingkat Pengetahuan Dokter}

Tingkat pengetahuan dokter ialah kemampuan dokter dalam menjawab pertanyaan yang tertera di kuesioner penelitian tentang Visum et Repertum perlukaan dimana setiap konten pertanyaan telah dihubungkan dengan skoring kualitas Visum et Repertum perlukaan. Pada penelitian ini didapatkan rerata tingkat pengetahuan dokter adalah 57.05\% (cukup). Tingkat pengetahuan terendah adalah $46.15 \%$ dan tertinggi $76.92 \%$. Hanya satu rumah sakit yang tingkat pengetahuan dokternya baik sedangkan rumah sakit lainnya masih jauh dari yang diharapkan.

Diketahui pada penelitian sebelumnya bahwa tingkat pengetahuan dokter mengenai Visum et Repertum dipengaruhi oleh pemahaman dokter mengenai Visum et Repertum yang tidak sama dan perbedaan prosedur masing-masing dokter dalam membuat Visum et Repertum. ${ }^{8}$

Diduga tingkat pengetahuan dokter yang masih belum baik ini disebabkan oleh para dokter yang tidak memperkaya ilmu pengetahuannya mengenai Visum et Repertum perlukaan setelah menamatkan pendidikan dokter. 
2. Kualitas Visum et Repertum Perlukaan.

Visum et Repertum perlukaan yang dibuat oleh seorang dokter dapat diketahui kualitasnya dengan menghitung skor dari Visum et Repertum perlukaan tersebut dengan menggunakan teknik skoring dari Bagian Forensik FKUI.

Hasil penelitian menunjukkan bahwa kualitas Visum et Repertum perlukaan yaitu 19.67\% (Buruk). Hal ini menunjukkan bahwa kualitas Visum et Repertum perlukaan di rumah sakit wilayah Sumatera Barat sangat mengecewakan. Kesalahan paling sering ditemukan yaitu pada variabel anamnesis, tanda vital, dan terapi yang diberikan yang sama sekali tidak dicantumkan dalam surat Visum et Repertum perlukaan. Anamnesis dicantumkan dalam bentuk mekanisme terjadinya trauma bukan anamnesis suatu penyakit yang nantinya anamnesis ini dapat juga diketahui oleh penyidik selaku peminta Visum et Repertum perlukaan setelah membacanya. Beberapa rumah sakit mencantumkan tanda vital tetapi yang dituliskan berupa tekanan darah, suhu, kesadaran dimana seharusnya dituliskan dalam bentuk kalimat yang berisikan tentang kesimpulan dari tanda vital tersebut bukan angka-angka dari pemeriksaan tanda vital. Begitu juga dengan terapi, tindakan terapi apa yang telah kita lakukan sangat penting dicantumkan dalam surat Visum et Repertum sebagai bahan pertimbangan derajat luka korban yang diperiksa yang nantinya dapat digunakan sebagai bahan pertimbangan penyidik.

Ada beberapa Visum et Repertum perlukaan yang tidak mencantumkan kesimpulan dari surat Visum et Repertum perlukaan dimana bagian kesimpulan adalah bagian terpenting dalam surat Visum et Repertum perlukaan untuk bahan pertimbangan seorang hakim dalam memutuskan suatu perkara pidana. Dalam kesimpulan minimal mencantumkan tiga konten yaitu: jenis luka, jenis kekerasan dan kualifikasi luka. Jenis luka juga sering ditemukan deskripsi yang tidak lengkap untuk setiap luka yang dituliskan dalam bagian pemberitaan. Dalam penulisan jenis kekerasan hampir seluruh pemeriksa menuliskan dalam Visum et Repertum perlukaan jenis kekerasan yang diakibatkan oleh benda tumpul atau benda tajam, penulisan seperti itu tidak benar karena pemeriksa tidak diperkenankan menyebutkan kata benda dalam jenis kekerasan, yang dituliskan hanya jenis kekerasan tumpul atau kekerasan tajam. ${ }^{6}$

Dari penelitian ini peneliti menyimpulkan sebenarnya kualitas Visum et Repertum perlukaan jauh lebih buruk dari hasil skor karena ditemukan kesalahan-kesalahan lain yang tidak termasuk di dalam salah satu variabel skoring kualitas Visum et Repertum seperti tidak menggunakan kop surat yang merupakan identitas dari instansi yang melakukan pemeriksaan, tidak menggunakan strip (-) setiap akhir kalimat guna mengakhiri kalimat tersebut agar tidak dapat ditambah dengan kata-kata lain dan juga terdapat Visum et Repertum yang tidak mencantumkan bagian penutup yang menyatakan bahwa surat Visum et Repertum dibuat mengingat sumpah jabatan sebagai dokter sesuai dengan Kitab Undang-Undang Hukum Acara Pidana.

3. Hubungan antara Tingkat Pengetahuan Dokter dengan Kualitas Visum et Repertum Perlukaan.

Analisis uji statistik menggunakan uji korelasi product moment dalam penelitian ini didapatkan nilai $p$ $=0,485(>0,05)$. Analisis uji statistik tersebut dapat disimpulkan bahwa tidak terdapat hubungan signifikan antara tingkat pengetahuan dokter dengan kualitas Visum et Repertum Perlukaan.

Hasil penelitian ini tidak sesuai dengan penelitian yang pernah dilakukan oleh Herkutanto pada 2004 yang mengemukakan salah satu faktor yang mempengaruhi kualitas Visum et Repertum adalah tingkat pengetahuan dokter pembuat Visum et Repertum. ${ }^{5}$

Penelitian ini belum bisa menemukan hubungan antara tingkat pengetahuan dokter dengan kualitas Visum et Repertum perlukaan. Dari pengamatan saat penelitian hal ini terjadi karena setiap rumah sakit yang berada di wilayah Sumatera Barat yang diteliti memiliki format tersendiri untuk Visum et Repertum yang untuk masing-masing rumah sakit berbeda sehingga dokter pembuat Visum et Repertum hanya mengisikan format yang telah ada. Format tersebut hanya memuat poin-poin secara garis besar dari Visum et Repertum. Walaupun format tersebut terdapat kesalahan dokter pembuat Visum et Repertum tetap mengisikan sesuai dengan format yang telah disediakan oleh rumah sakit. Seharusnya 
rumah sakit tidak menyediakan format untuk Visum et Repertum tetapi sebuah buku panduan untuk dokter dalam membuat Visum et Repertum dimana di dalam buku itu dijelaskan bagaimana cara penulisan yang benar. Peneliti juga menilai bahwa pengetahuan dokter mengenai Visum et Repertum tersebut hanya sebatas teori dan belum sempurna jika diaplikasikan ke dalam kasus-kasus Visum et Repertum yang beragam.

\section{KESIMPULAN}

Rerata tingkat pengetahuan dokter mengenai Visum et Repertum di rumah sakit wilayah Sumatera Barat adalah 57.05\% (Cukup). Rerata kualitas Visum et Repertum perlukaan di rumah sakit wilayah Sumatera Barat adalah 19.67\% (Buruk).

Tidak terdapat hubungan yang bermakna antara tingkat pengetahuan dokter dengan kualitas Visum et Repertum perlukaan.

\section{DAFTAR PUSTAKA}

1. Sampurna B, Zulhasmar S, TjeTjep DS. Peranan ilmu forensik dalam penegakan hukum. Jakarta. IImu Kedokteran Forensik Universitas Indonesia; 2008; 168-86.

2. Herkutanto. Peningkatan kualitas pembuatan
Visum et Repertum (VeR) kecederaan di rumah sakit melalui pelatihan dokter unit gawat darurat. Jakarta: Departemen IImu Kedokteran Forensik FKUI; 2005.

3. Herkutanto. Pemberlakuan pembuatan Visum et Repertum(VeR) korban hidup dan trauma-related injury severity score (TRISS) untuk Meningkatkan kualitas VeR. Jakarta: Departemen IImu Kedokteran Forensik FKUI; 2005.

4. Atmadja. Simposium Tatalaksana Visum et Repertum korban hidup pada kasus perlukaan dan keracunan di rumah sakit. Jakarta: RS Mitra Kepala Gading; 2004.

5. Herkutanto. Kualitas visum et Repertum perlukaan di Jakarta dan faktor yang mempengaruhi. Majalah Kedokteran Indonesia. 2004;54(9):355-60.

6. Afandi D. Visum et Repertum pada korban hidup. Jurnal IImu Kedokteran. 2009; 3(2):79-84.

7. Susanti R. Kualitas Visum et Repertum perlukaan pada rumah sakit di wilayah Sumatera Barat tahun 2008. Padang: Bagian IImu Kedokteran Forensik FKUA; 2008.

8. Nuraga R. Perbedaan tingkat pengetahuan dokter umum tentang Visum et Repertum. Jurnal Penelitian Media Medika Muda. 2012;13(6):234-8. 